\title{
PHYTOCHEMICAL INVESTIGATION AND IN VITRO ANTIMICROBIAL SCREENING OF SANTALUM ALBUM SEEDS EXTRACTS
}

\author{
GAUTAM P. VADNERE*, MD. RAGEEB USMAN, SANTRAM LODHI, VAISHALI PATIL \\ Department of Pharmacognosy, Smt. Sharadchandrika Suresh Patil College of Pharmacy, Chopda, Jalgaon 425107, M. S. India \\ Email: gautamvadnere31@rediffmail.com
}

Received: 08 Jul 2017 Revised and Accepted: 21 Sep 2017

\begin{abstract}
Objective: Aim of the present study was to perform phytochemical evaluation and antimicrobial screening of petroleum ether and ethanol extracts of Santalum album seeds.

Methods: Petroleum ether and ethanol extracts were screened for the presence of chemical constituents. Petroleum ether extract was investigated detail by using chromatographic and spectroscopic methods. In vitro antimicrobial activity of both extracts were investigated using disc diffusion method on two gram-positive bacteria, Bacillus subtilis, Staphylococcus aureus, gram-negative Pseudomonas aeruginosa, Escherichia coli and fungus Candida albicans.

Results: Santalbic acid was identified in petroleum ether extract and content determined by HPTLC was $4.7 \%$ w/w. It was seen that petroleum ether extract have MIC value for B. subtilis, P. aeruginosa, E. coli and C. albicans were $78.125 \mu \mathrm{g} / \mathrm{ml}, 19.331 \mu \mathrm{g} / \mathrm{ml}, 625 \mu \mathrm{g} / \mathrm{ml}$ and $39.062 \mu \mathrm{g} / \mathrm{ml}$ respectively while MBC was $39.062 \mu \mathrm{g} / \mathrm{ml}, 4.882 \mu \mathrm{g} / \mathrm{ml}, 312.5 \mu \mathrm{g} / \mathrm{mland} 9.765 \mu \mathrm{g} / \mathrm{ml}$, respectively. Petroleum ether extract showed MIC and MBC values for $S$. aureus was similaras $156.25 \mu \mathrm{g} / \mathrm{ml}$. So, the petroleum ether extract showed significant antimicrobial activity against both grams positive, gram negative and fungal strain.
\end{abstract}

Conclusion: The results of present investigations were indicative of possible high potency of petroleum ether extract due to santalbic acid which could serve as chemotherapeutic agent.

Keywords: Santalum album, Antimicrobial, Santalbic acid, HPTLC, Sandalwood

(C) 2017 The Authors. Published by Innovare Academic Sciences Pvt Ltd. This is an open access article under the CC BY license (http://creativecommons.org/licenses/by/4.0/) DOI: http://dx.doi.org/10.22159/ijpps.2017v9i11.21216

\section{INTRODUCTION}

Santalum album Linn. (family: Santalaceae) is an evergreen small tree, a partial root parasite, attaining a height of 12 to 13 meters and girth of 1 to 2.4 meters with slender drooping as well as erect branching [1].Historical review reveals that sandalwood has been referred to in Indian mythology, folklore and ancient scriptures. In India, S. album L. is found all over the country, with over $90 \%$ of the area in Karnataka and Tamil Nadu [2, 3].Medicinally $S$. album is useful in biliousness, fever and thirst. Extremely, a paste of $S$. album is used at scorpion bites, inflamed site and skin eruption. It is commonly used in cosmetic and hair oil. Sandalwood oil relieves itching, pruritus, inflammation of the skin. It is most effective in relieving dehydrated skin so that it making great for anti-ageingskincare. The sandalwood oil is apopular remedy in gonorrhoea, chronic bronchitis, cystitis, gleet, urethral haemorrhage and scabies. S.album L. is bitter, cooling, sedative diuretic, expectorant, stimulant and has astringent actions. It is disinfectant to mucous membrane in genitor-urinary and bronchial tracts. Good for memory and act as blood purifier[2, 3].The essential oil has antibacterial, antifungal action and used in dysuria, urethral discharges and gallbladder diseases. Sandalwood is bacteriostatic against gram-positive bacteria and used as a urinary antiseptic in chronic cystitis and sexually transmitted diseases [4].

The heartwood contains essential oil, dark resin and tannic acid [2]. The essential oilcontains amixture of sesquiterpene alcohols especially $\alpha$-trans-bergamotol, cis- $\alpha$-santalol, cis- $\beta$-santalol, epi-cis$\beta$-santalol with asmallamount of trans- $\beta$-santalol and cis-lanceol [5]. Other chemical constituent'spresents in the heartwood of S. album L. includes hydrocarbons $\alpha$-santene and $\beta$-santene, the alcohols santenol, teresantalol, the aldehydes nortricycloecasantalol and isovaleraldehyde, the ketones santenone, santalone with santalic acids [6]. Other hydrocarbons such as $\alpha$-santalene, $\beta$-santalene, $\alpha$ bergamotene and epi- $\beta$-santalene are also present in the oil as well as $\alpha$-curcumene, $\beta$-curcumene, $\gamma$-curcumene, $\beta$-bisabolene and $\alpha$ - bisabolol are also reported in heartwood [6]. New antitumor sesquiterpenoid from $S$. album L. also reported in methanolic extract of heartwood[7].From Indian origin heartwood of $S$. album, some new bisabolane and santalane type of sesquiterpenoids along with $(+) \alpha$-nuciferol, (+) citronellol and geraniol were isolated[8].More oil constituents including santalone, 3-dien-1-yl methyl ketone, 4methylcyclohexa-1, (E)-5-(2, 3-dimethyl-3-nortricyclyl)-pent-3-en2-one and 5, 6-dimethyl-5-norbornen-exo-2-olwere identified [9].Indian sandalwood oil also confirmed two new sesquiterpene aldehydes as Cyclosantalal and epicyclosantalal[10]. The heartwood oil of $S$. albumL. Contains bisabolenals $\mathrm{A}$ to $\mathrm{E}$ and $\alpha$-transbergamotenol [11].

The seed oil of $S$. albumis dark red viscid fixed oil containing santalbic acid (or Ximenynic acid) and stearolic acid (9octadecynoicacid) $[12,13]$. The seed oil from young and mature trees contains santalic acid, saturated fatty acid, nitrogen, protein, $\mathrm{K}_{2} \mathrm{O}$, $\mathrm{CaO}, \mathrm{MgO}, \mathrm{Fe}_{2} \mathrm{O}_{3}, \mathrm{P}_{2} \mathrm{O}_{5}$. A calcium-dependent protein kinase is expressed in sandalwood seeds under developmental regulation, and it is localized with spherical storage organelles in the endosperm [14]. Aim of the present study was to perform phytochemical evaluation and antimicrobial screening of petroleum ether and ethanol extracts of Santalum album seeds to find out the most effective extract.

\section{MATERIALS AND METHODS}

\section{Chemicals and reagents}

All reagents and chemicals were of analytical grade. Silica gel GF254, was purchased fromMerck Life Science Private Limited, Mumbai, India. Dimethyl sulfoxide and other reagents were purchased from Sigma Chemical Co. (USA). Santalbic acid marker was obtained from the Sami Labs Ltd., Bangalore. All media were used of Hi media Pvt Ltd. 


\section{Collection and identification of plant material}

$S$. albumseeds were authenticated and herbarium with voucher specimen (No. VAISA4) was deposited in Botanical Survey of India (BSI), Pune, Maharashtra, India.Seeds of the S. album were collected in the month of August 2009, from Indore (MP), India. The seeds were dried under theshed and stored.

\section{Extraction and phytochemical screening}

The collected seeds of $S$. album were washed with water to clean forsoil and earthy matter. Clean seeds were dry in sunlight followed by air drying under the shed for two days up to complete drying. The dried seeds were converted into coarse powder by using mixer grinder and stored for further processing. A weighed amount of seed powder was subjected for continuous hot extraction by using Soxhlet apparatus with petroleum ether $\left(60-80^{\circ} \mathrm{C}\right)$ for $72 \mathrm{~h}$. After complete extraction with petroleum ether, the mark was air dried and further subjected to extraction with ethanol $(95 \% \mathrm{v} / \mathrm{v})$.The extracts were concentrated under reduced pressure andyield was calculated with reference ofair-dried basis. Finally, the extracts were screened qualitatively for the major groups of chemical constituents using standard methods[15].

\section{Fractionation of petrolium ether extract of $S$. album seeds by} preparative thin layer chromatography (TLC)

To speed up the separation and to make them online for continuous recording varrious modification of preparative TLC have been developed. In general microgramamount of mixture are separatedin analytical TLC. In preparative TLC thicker layer of sorbent are employed. Seperated band of thecompound are scrapped from the plate and subjected to solvent extraction with amodern spectrometric method for structure determination.

Preparative TLC plates were prepared using aslurry of silica gel GF254 by pouring technique. The plates were activated at $110^{\circ} \mathrm{C}$ for $1 \mathrm{hr}$. The sample was prepared in petroleum ether and applied as a band on the plate. Sample overloading was avoided to reduce tailing effect. Then the plates were dried in air and developed in the presaturated developing chamber using the solvent system nhexane/diethyl ether/acetic acid (85:15:5). The substances separated as distinct bands. The spots were scraped and dissolve in petroleum ether. Prepared the dilution of the solution for UV spectrophotometer analysis to measure absorbance.

\section{Column chromatography ofpetrolium etherextract of $S$. album seeds}

Column chromatography is an important useful technique used for the separation and purification of both solids and liquids. Based on TLC profile of extract, the petroleum ether extract of $S$. album was further fractionated by silica gel column chromatography.

The stationary phase Silica (Merck, 60-120 mesh) bed was prepared in mobile phase in the glass column (size $45 \times 4.5 \mathrm{~cm}$ ), the bed (final geometry $35 \mathrm{~cm} \times 4.5 \mathrm{~cm}$ ) was allowed to settle with gentle taping after each addition, in order to ensure the uniform packing. Mobile phasen-hexane/diethyl ether/acetic acid (85:15:5) wasrun through the column after loading of the sample to elute different fractions. A linear solvent flow rate was maintained as 42 drops/min and $50 \mathrm{ml}$ of each fraction were collected. The collected fractions were subjected to TLC and were concentrated to dryness at normal temperature. The collected fractions were also subjected to ultraviolet spectrophotometer analysis.Selected fractions were characterized by FTIR and NMR spectral analysis.

Determination of santalbic acid content in S.album by highperformance thin layer chromatography (HPTLC)method

HPTLC is a versatile technique for qualitative and quantitative analysis of herbal extracts. This technique includes fingerprint profiles of extract and estimation of different markers and biomarkers. Quantitative estimation of santalbic acid was carried out by HPTLC method. Santalbic acid marker was obtained from the Sami Labs Ltd., Bangalore, as a gift sample.

Weighed 9.8mg of marker santalbic acid and dissolved in n-hexane $(1.96 \mathrm{mg} / \mathrm{ml})$. Marker solution was stored in an amber colored flask.
The sample solution was prepared as $74.46 \mathrm{mg} / \mathrm{mlof}$ petroleum etherextract $5 \mathrm{ml}$ of $\mathrm{n}$-hexane. The sample solutionwas stored in an amber coloured flask. Precoated TLC plates of Silica gel G 60 F254 (E. Merck), $10 \times 20 \mathrm{~cm}$ in size on the aluminium support of 200 $\mu$ mthickness were used as stationary phase.Amixture of $n$-hexane: diethyl ether: acetic acid (85:15:5) was used as mobile phase.10 $\mu \mathrm{l}$ of marker and sample solutions was applied as band length $10 \mathrm{~mm}$ from lower edge of the plate using $100 \mu \mathrm{l}$ syringe on CAMAG LINOMAT5 automatic sample applicator on precoated TLC plates. Plates were developed in previously saturated, $20 \times 20 \mathrm{~cm}$ twin trough (CAMAG) chamber. Plates were then air dried for $10 \mathrm{~min}$ and scanned by using CAMAG TLC scanner 3 in Remission/Fluorescence Mode with WINCATS software. The temperature should be $25 \pm 20 \mathrm{C}$, and relative humidity $40 \%$. The profile obtained was documented at $254 \mathrm{~nm}, 366$ $\mathrm{nm}$ through thevisible camera (CAMAG Visualizer: 150503).

\section{In vitro screening for antimicrobial activity}

\section{Test organisms and other materials}

Selected test organisms weregram-positive bacteria Bacillus subtilis(ATCC 6633), Staphylococcus aureus (ATCC 6538),gramnegative Escherichia coli (ATCC 10538), Pseudomonas aeruginosa (ATCC 27853) and fungus Candida albicans (ATCC 10239) obtained from the Department of Microbiology, R. C. Patel Art Science and Commerce College, Shirpur Maharashtra, India. All test organisms were cultured aseptically at $37{ }^{\circ} \mathrm{C}$ in nutrient agar medium for overnight. Fungi were cultured at $30{ }^{\circ} \mathrm{C}$ in potato dextrose agar medium for 3-5 d.All media were used of Himedia Pvt Ltd. Nutrient agarmedia for bacteria and potato dextrose agar were selected for fungi. The sterilization of mediaand all glassware were done by autoclaving at temp $121^{\circ} \mathrm{C}$ and pressure 15 Psig for $15 \mathrm{~min}$.

\section{Disc diffusion method}

Filter paper disks were prepared by cutting paper disks of about $6 \mathrm{~mm}$ in diameter from whatman filter paper (No: 41). The paper disks were flattened by spreading on a clean smooth surface of thepetri dish and pressed by rolling a bottle repeatedly and sterilized in an autoclave [16].

The stock solution was prepared in dimethyl sulfoxide (DMSO) at a concentration $5000 \mu \mathrm{g} / \mathrm{ml}$. Accurately weighed $2 \mathrm{~g}$ of the each extract and dissolved in $400 \mathrm{ml}$ of DMSO solution. The solutions were stored in the refrigerator at $4{ }^{\circ} \mathrm{C}$. Stock cultures were maintained at $4{ }^{\circ} \mathrm{C}$ on slopes of nutrient agar in test tubes. Active cultures for experiments were prepared by selecting at least three to five well-isolated colonies of the same morphological type from the stock cultures [17]. The colony is transferred with a loop into a test tube having 4 to $5 \mathrm{ml}$ of a nutrient agar media for bacteria and incubated without agitation for $24 \mathrm{~h}$ at $37^{\circ} \mathrm{C}$. The experiment was performed under strict aseptic conditions. Potato dextrose agar medium was used for fungi and incubated without agitation for $3-5 \mathrm{~d}$ at $30^{\circ} \mathrm{C}$.

\section{Application of discs to inoculated agar plates}

Sterile $6 \mathrm{~mm}$ disc filter paper disc were impregnated with $100 \mu \mathrm{L}$ of the plant extracts. Discs were transferred on the agar with sterilized forceps. Each disc must be pressed down to ensure complete contact with the agar surface. They distributed evenly so that they are no closer than $24 \mathrm{~mm}$ from centre to centre. The plates are placed in freezing condition for $5 \mathrm{~min}$ and were incubated at $37 \pm 0.1^{\circ} \mathrm{C}$ for 24 $\mathrm{hr}$, while yeast plates were incubated at $28 \pm 0.1^{\circ} \mathrm{C}$ for $48 \mathrm{~h}$ in the incubator. After incubation, each plate is examined. The diameters of the zones of complete inhibition are measured, including the diameter of the disc with the help of aruler. The diameter of these zones was measured in millimeters.

\section{Determination of minimum inhibitory concentration (MIC)}

MIC is defined as the lowest concentration where no visible turbidity is observed in the test tube (bacteriostatic concentration). Broth dilution technique was utilized in which a stock solution of test extract was prepared with the highest concentration of $5 \mathrm{mg} / \mathrm{ml}$ in sterile water and makes serially dilutions concentration ranging from 0.5 $\mathrm{mg} / \mathrm{ml}$ to $5 \mathrm{mg} / \mathrm{ml}$ using nutrient broth. These were inoculated with $0.2 \mathrm{ml}$ suspension of test organisms. The test tubes were observed for turbidity after $18 \mathrm{~h}$ of incubation at $37^{\circ} \mathrm{C}$. The least concentration 
which does not shows turbidity was observed and noted as the minimum inhibitory concentration (MIC) value $[18,19]$

\section{Determination of minimum bacterial concentration (MBC)}

MBCis defined as the lowest concentration at which no bacterial growth is observed (bacteriocidal concentration). MBC was determined by subculturing of MIC tubes in antimicrobial-free agar plates. The content of the test tubes was streaked using a sterile wire loop on agar plate free of bacteria and incubated at $37{ }^{\circ} \mathrm{C}$ for 18 h. The lowest concentration of the extract which showed no bacterial growth was noted and recorded as the MBC.

\section{Statistical analysis}

All experiments were performed in atriplicate manner in antimicrobial test analysis. The data were expressed as mean values \pm SD using In Stat software and tested with analysis of variance followed by the multiple comparison tests of TukeyKramer with $\mathrm{P}<0.01$ were considered significant.

\section{RESULTS}

\section{Phytochemical screening and preparative TLC}

Preliminary screening of petroleum ether extract (yield was $14.66 \%$ $\mathrm{w} / \mathrm{w}$ ) was revealed the presence of steroids, terpenoids, and fatty acids. The presence of glycosides and phenolic compounds was confirmed in the ethanolic extract (yield 9.03\%).Based on the type of chemical constituents, the different solvents were tried to find out best separation in thin layer chromatography. The best separation was found insolvent system, n-hexane/diethyl ether/acetic acid (85:15:5). The plates were observed under ultraviolet light and bands recorded with respect to retardation factor $(\mathrm{Rf})=0.7$ (fraction A), 0.6 (fraction B), and 0.4 (fraction $\mathrm{C}$ ) adwere scraped off. UV absorbance of fraction A, B and C having Rf value was 0.7, $0.6,0.4$ receptively.UV spectrum of petroleum ether extract and standard santalbic acid showed absorption at $\lambda \max 202.0 \mathrm{~nm}$ and $209.8 \mathrm{~nm}$.

Column chromatography ofpetrolium ether extract of $S$. album seeds

Column chromatography of petrolium ether extract produces different fractions. After TLC of different fractions was confirmed those fractions from 9 to 11 have a single spot with similar Rf 0.27 that was identical to the Rf value of santalbic acid. Further isolated fraction 9 to 11 were combined and characterized by IR and NMR spectral analysis.

IR spectrum showed (fig. 1) characteristic broad peak at 3430.83 $\mathrm{cm}^{-1}$ ruled out the possibility of presence of an acid. IR spectrum sharp peaks characteristic at $893 \mathrm{~cm}^{-1}$ (-C=C-disubstituted olefinic), $1298 \mathrm{~cm}^{-1}(-\mathrm{C}-0-), 1760 \mathrm{~cm}^{-1}$ (Acetic carbonyl-C=0), $3019 \mathrm{~cm}^{-1}$ ($\mathrm{C}=\mathrm{CH}-), 2959 \mathrm{~cm}^{-1}$ (Alkane-C-H), $1008.62 \mathrm{~cm}^{-1}, 2361 \mathrm{~cm}^{-1}(-\mathrm{C} \equiv \mathrm{C}-)$ $2328 \mathrm{~cm}^{-1}, 1610 \mathrm{~cm}^{-1}\left(-\mathrm{C}=\mathrm{C}\right.$-Aliphatic), $1423 \mathrm{~cm}^{-1}, 1126 \mathrm{~cm}^{-1}(-\mathrm{C}=0$ Hetro atom).

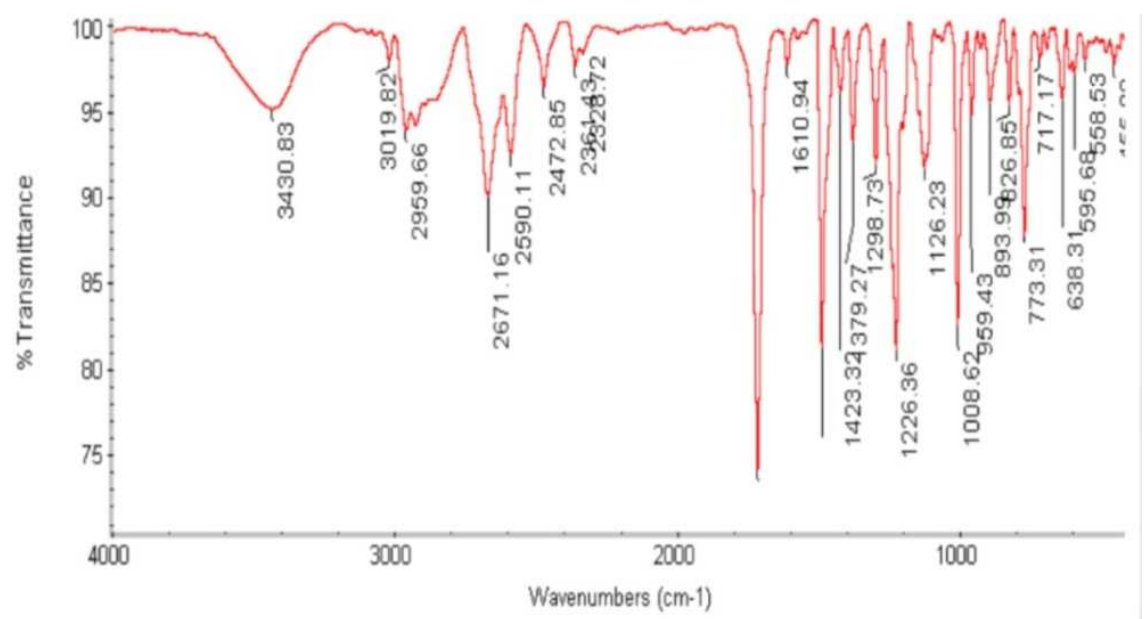

Fig.1: FTIR spectrum of isolated santalbic acid

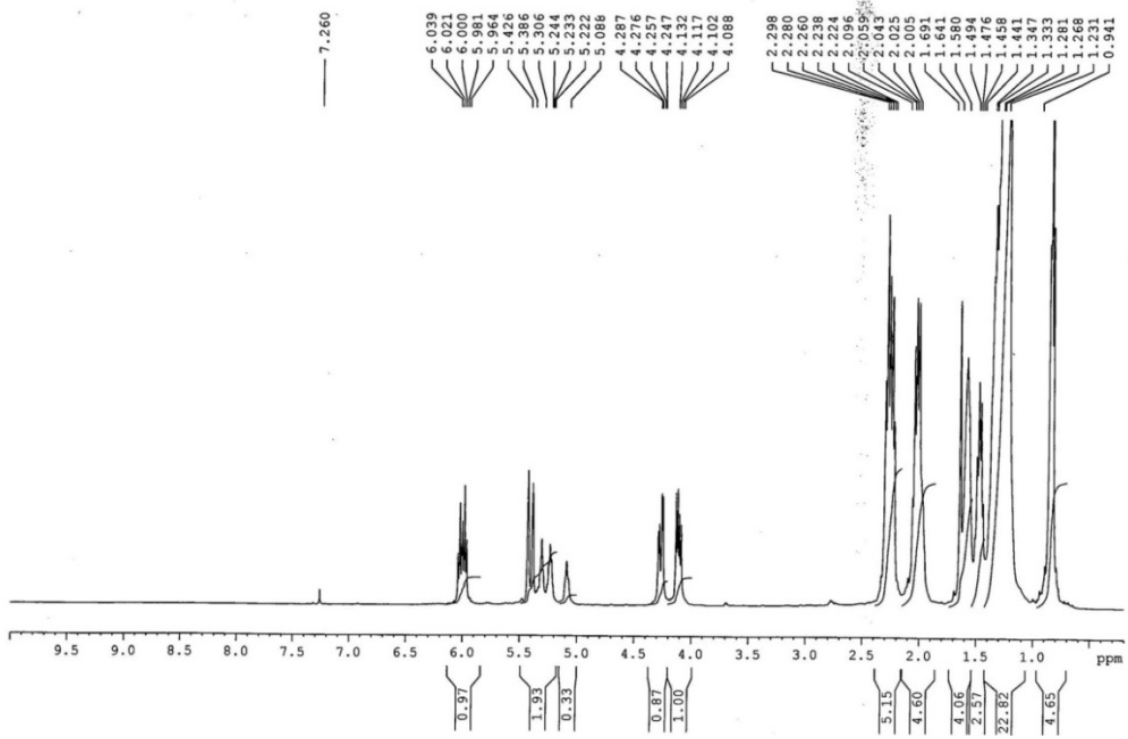

Fig.2: H-NMR spectrum of isolated santalbic acid 


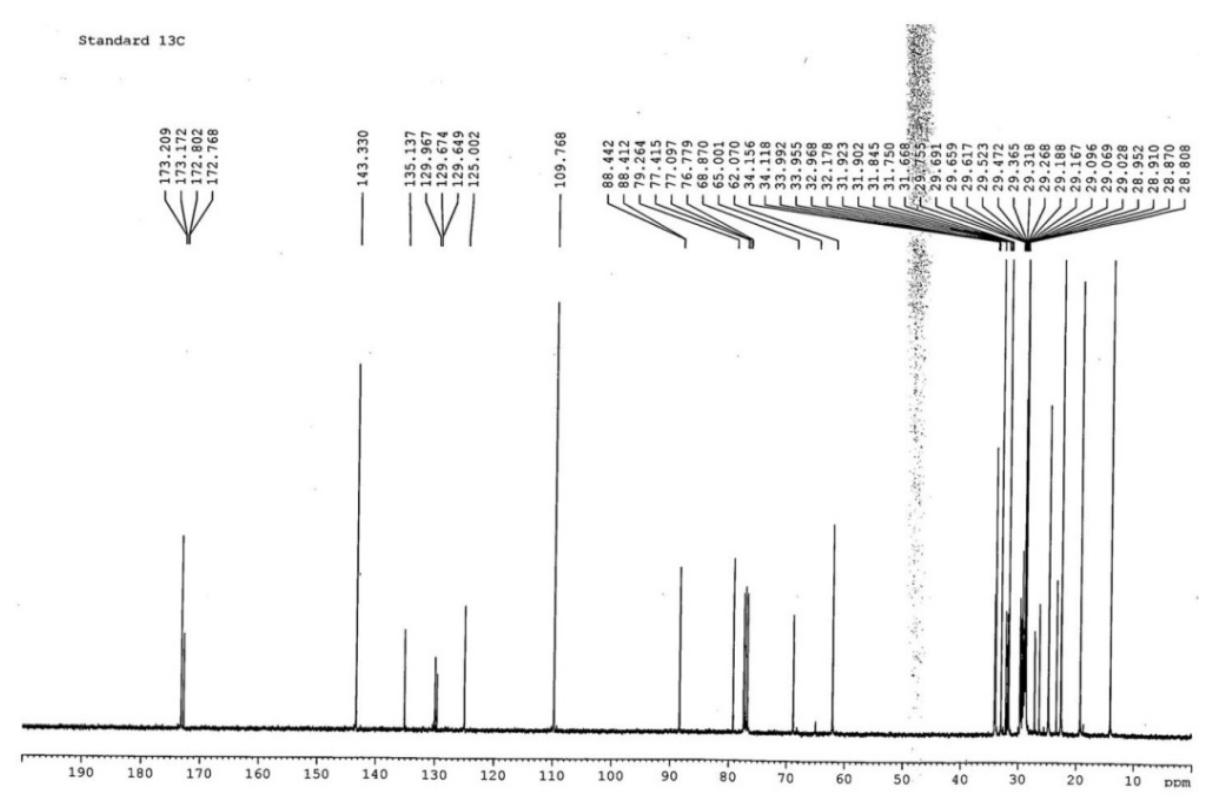

Fig.3: C-NMR spectrum of isolated santalbic acid

Proton NMR spectrum showed unsaturation at $6.039 \mathrm{ppm}$ and peak at $5.426 \mathrm{ppm}, 2.260 \mathrm{ppm}$ due to ethylenic and methylene proton atom respectively. These are comparable with reported data of synthetic methyl ester of santalbic acid.[18] While other peak and signals at $\delta$ value $0.94(\mathrm{~T}, 3 \mathrm{H}), 1.24(\mathrm{Q}, 28 \mathrm{H}), 1.44(\mathrm{M}, 3 \mathrm{H}), 1.64(\mathrm{M}$, $4 \mathrm{H}), 2.0(\mathrm{Q}, 5 \mathrm{H}), 2.26(\mathrm{Q}, 6 \mathrm{H}), 4.0(\mathrm{~T}, 1 \mathrm{H}), 4.4(\mathrm{~T}, 1 \mathrm{H}), 5.5(\mathrm{~T}, 1 \mathrm{H}), 6.0$ (M, 1H) was also seen in proton NMR (fig. 2 ).

The result obtained from ${ }^{13} \mathrm{C}$ NMR spectrum showed strong peak due ethylenic carbon atom at $143.33 \mathrm{ppm}$ and $109.768 \mathrm{ppm}$. While due to E-enyne system it shows apeak at $32.968 \mathrm{ppm}$ and 19.297 ppm (Methylene carbon atom) which are comparable with reported data of synthetic methyl ester of santalbic acid. Also the other peak and signals at $\delta$ value 110 (C-9, $10 \mathrm{~S}), 130$ (C-7, 8 D), 173 (C-18, S), 29 (C-1 Q), 30 (C-2 T), $31.8(\mathrm{C}-5,13,12 \mathrm{~T}), 34(\mathrm{C}-11,12,4,16,6,17 \mathrm{~T})$, $22.8(15,14,3 \mathrm{~T})$ was seen (fig. 3$)$.

\section{HPTLC analysis of petroleum ether extract of Santalum album}

HPTLC chromatogram of crude petroleum ether extract of $S$. album Linn. seed at $235 \mathrm{~nm}$ (Sample $10 \mu \mathrm{l}$ ) shows a spot with Rf value 0.21 (100.00)(table 1, fig. 4). HPTLC chromatogram of marker Santalbic acid at $235 \mathrm{~nm}$ (Sample $10 \mu \mathrm{l}$ ) shows Rf value at 0.22 (100.00). From above Rf values of extract and marker Santalbic acid, specificity of one marker component with Rf 0.21 was Santalbic acid in S. album by comparing with marker Santalbic acid[20]. HPTLC chromatogram for fraction of petroleum ether extract of $S$. albumLinn. at $235 \mathrm{~nm}$ (Sample $10 \mu \mathrm{l}$ ) shows Rfvalue at $0.21(100.00)$ while HPTLC chromatogram of marker Santalbic acid at $235 \mathrm{~nm}$ (Sample $10 \mu \mathrm{l}$ ) shows Rf value at 0.22 (100.00). From above Rf values of $S$. album Linn. seed and marker Santalbic acid, specificity of one marker component with Rf 0.21 was $4.7 \%$ w/w Santalbic acid in S. album Linn. seeds by comparing with marker Santalbic acid (fig. 5).

\section{In vitro antimicrobial activity}

Ethnobotanical importance of $S$. album has been investigated and studied by various authors. They reported antimicrobial activity of essential oil obtained from heartwood, yet was no work on antimicrobial activity of fixed oil obtained from seeds of S. album L. The data obtained from disc diffusion method are used for comparative study of two extracts of S. album L. seed such as petroleum ether extract and alcoholic extract was shown in table 2 (fig. 6 and 7).

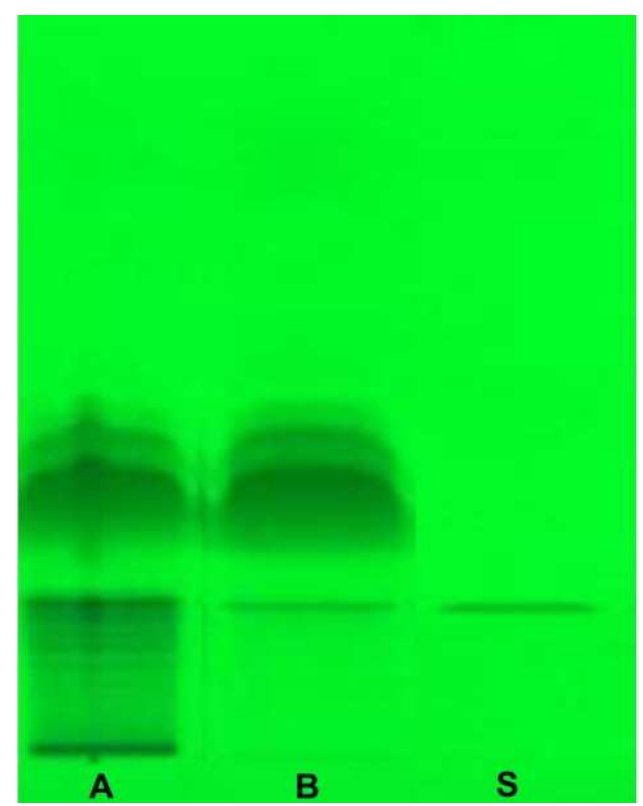

Fig.4: Photograph of HPTLC plate for (A) Crude petroleum ether extract; (B) Fraction of petroleum ether extract; (S) Standard santalbic acid, detection at $254 \mathrm{~nm}$

Table 1: HPTLC profile of Santalum album extract, fraction and standard santalbic acid

\begin{tabular}{|c|c|c|c|c|c|c|c|c|c|c|}
\hline Track & Peaks & Start Rf & Start height (AU) & Max Rf & Max height (AU) & Max \% & End Rf & End height (AU) & Area (AU) & Area \% \\
\hline 1 & 1 & 0.21 & 0.0 & 0.25 & 302.0 & 100 & 0.27 & 2.3 & 7277.0 & 100 \\
\hline 2 & 1 & 0.21 & 5.4 & 0.24 & 314.6 & 100 & 0.27 & 0.4 & 6414.5 & 100 \\
\hline 3 & 1 & 0.22 & 0.1 & 0.25 & 654.2 & 100 & 0.29 & 0.4 & 111077.3 & 100 \\
\hline
\end{tabular}



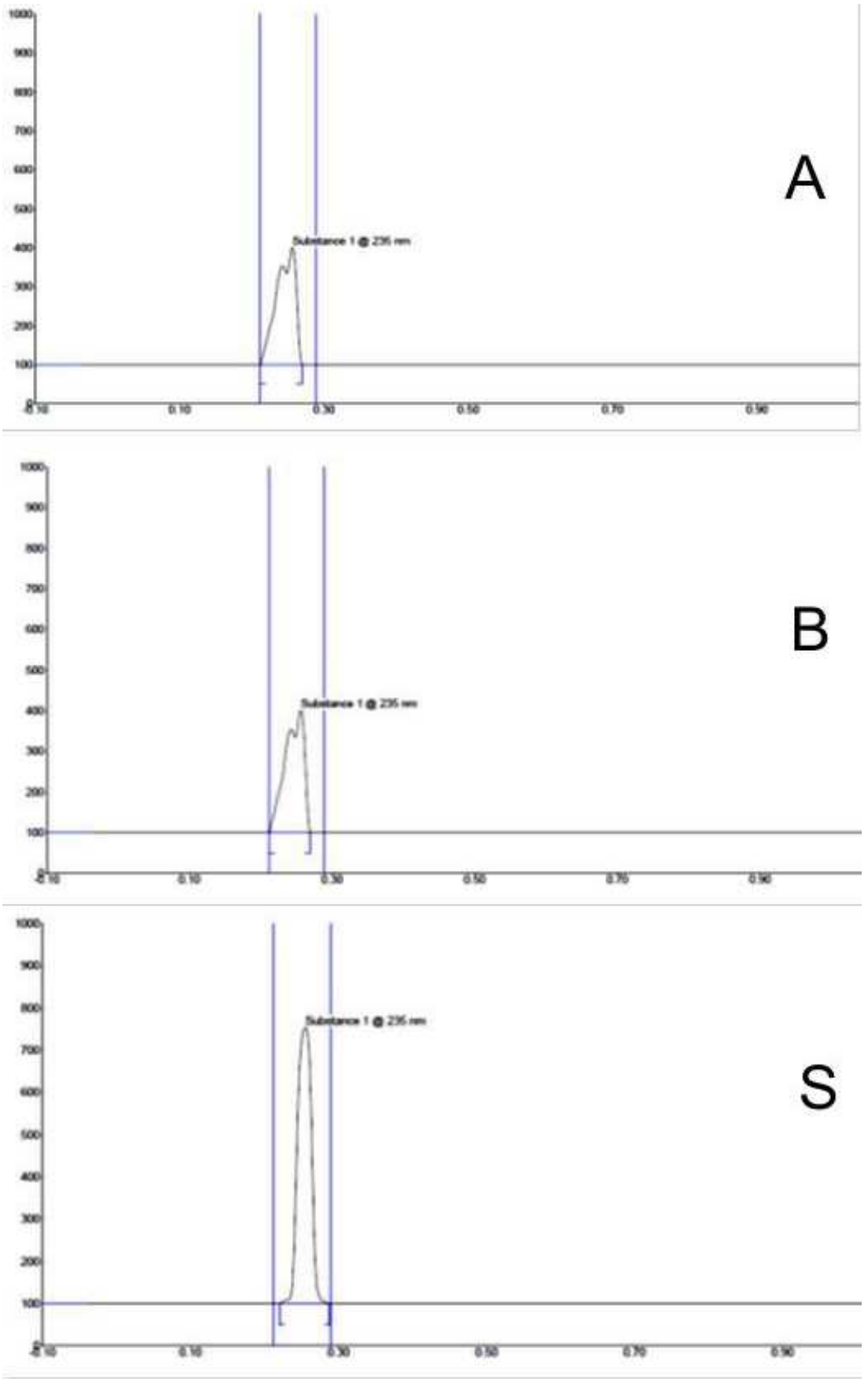

Fig.5: HPTLC chromatogram of (A)Petroleum ether extract of Santalum album seeds (B) Fraction of petroleum ether extract of Santalum album seeds (S) Standard santalbic acid at $235 \mathrm{~nm}$

Table 2: Antimicrobial activity of plant extracts against test microbial

\begin{tabular}{lllll}
\hline Test organisms & Strains & $\begin{array}{l}\text { Conc. } \\
\text { (mg/ml) }\end{array}$ & \multicolumn{2}{c}{ mean \pm SD of diameter for zone of inhibition (mm) } \\
\cline { 3 - 5 } & & Petroleum ether extract & Alcoholic extract \\
\hline Gram positive & B. subtilis & 5.0 & $13.66 \pm 2.08^{*}$ & $9.01 \pm 0.35$ \\
Gram positive & S. aureus & 5.0 & $11.33 \pm 0.57^{*}$ & - \\
Gram negative & P. aeruginosa & 5.0 & $6.4 \pm 0.30$ & - \\
Gram negative & E. coli & 5.0 & $7.3 \pm 0.26$ & $6.2 \pm 1.00$ \\
Fungi & C. albicans & 5.0 & $13.66 \pm 0.5^{*}$ & - \\
\hline
\end{tabular}

$\mathrm{n}=3$, value represented as mean $\pm S D . * P<0.01$ were considered significant; $(-=$ absent $)$

Petroleum ether extract of seed of $S$. album was more active against B.subtilis and fungus $C$. albicans (zone of inhibition $13.66 \pm 2.08 \mathrm{~mm}$,
$13.66 \pm 0.5 \mathrm{~mm}$ respectively). While the alcoholic extract was not sufficient active against all five microbes. Petroleum ether extract of 
seed of S. album was also active against gram-positive bacteria $S$. aureus (zone of inhibition $11.33 \pm 0.57 \mathrm{~mm}$ ) while it is less effective against gram-negative bacteria P. aeruginosa and E. coli (zone of inhibition $6.4 \pm 0.30 \mathrm{~mm}$ and $7.3 \pm 0.26 \mathrm{~mm}$, respectively). Observations found that the MIC and MBC values of the petroleum ether extract for $S$. aureus was same as $156.25 \mu \mathrm{g} / \mathrm{ml}$.
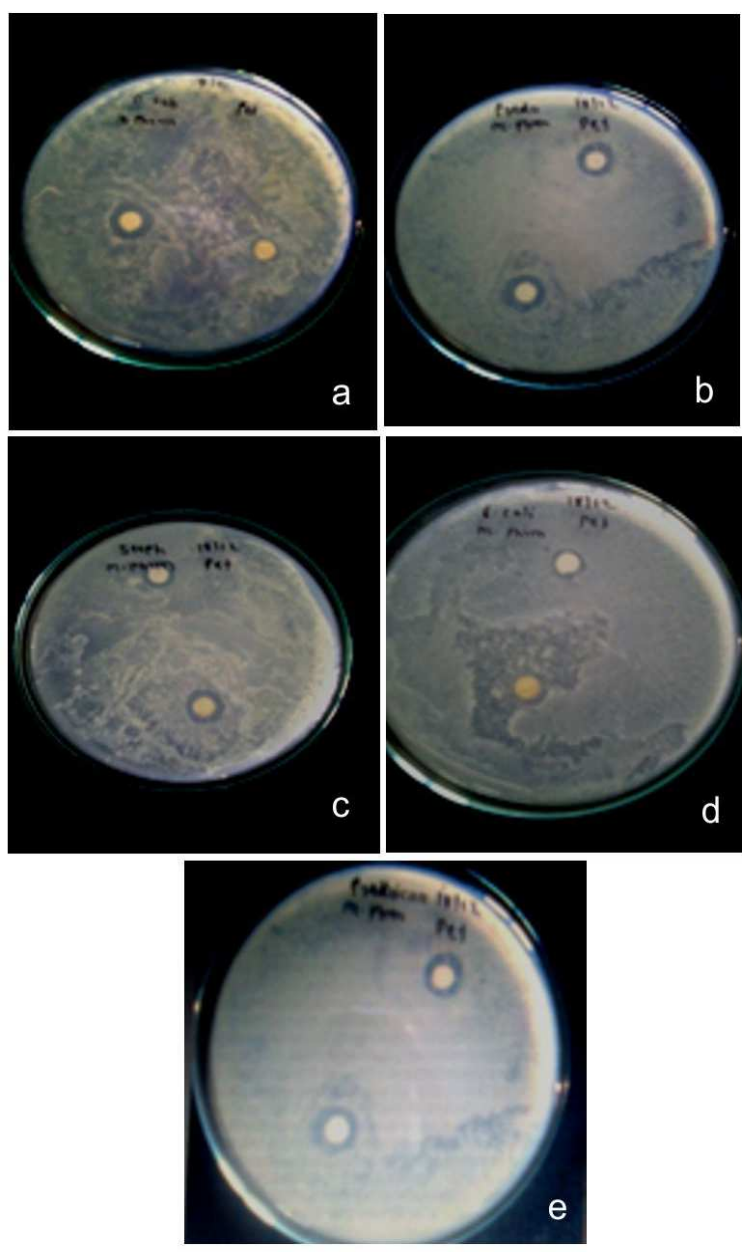

Fig.6: Zone of inhibition of petroleum ether extract and standard on nutrient agar by discs diffusion method
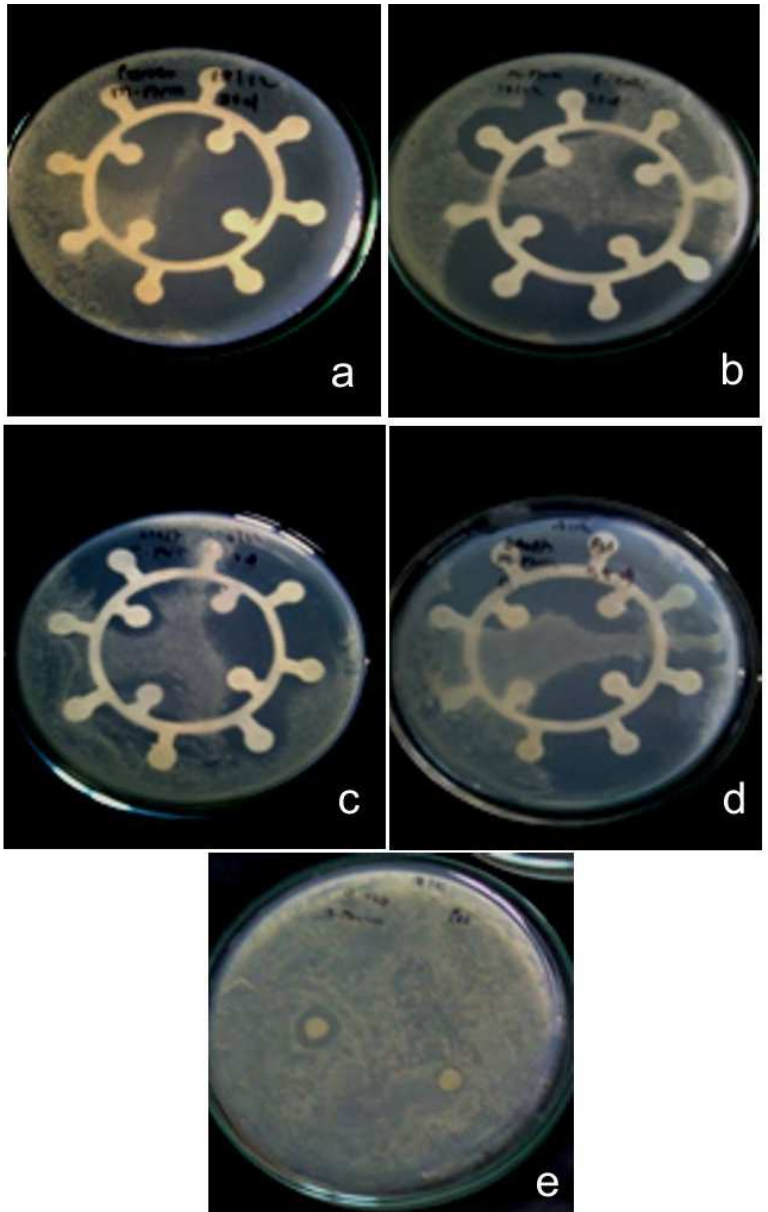

Fig.7: Zone of inhibition of ethanol extract and standard antibiotic on nutrient agar by disc diffusion method

In general most bactericidal antimicrobials, the MIC and MBC are approximately same or nearas in present study it has typically been observed (table 3 and 4). It was seen that the MIC value for $B$. subtilis, P. aeruginosa, E. coli and C. albicans was $78.125 \mu \mathrm{g} / \mathrm{ml}$, $19.331 \mu \mathrm{g} / \mathrm{ml}, 625 \mu \mathrm{g} / \mathrm{ml}$ and $39.062 \mu \mathrm{g} / \mathrm{ml}$ respectively while MBC was $39.062 \mu \mathrm{g} / \mathrm{ml}, 4.882 \mu \mathrm{g} / \mathrm{ml}, 312.5 \mu \mathrm{g} / \mathrm{ml}$ and $9.765 \mu \mathrm{g} / \mathrm{ml}$, respectively.

Table 3: Minimum inhibitory concentration (MIC) values for bacterial strain against petroleum ether extract of $S$. album seeds

\begin{tabular}{|c|c|c|c|c|c|}
\hline $\begin{array}{l}\text { Concentration } \\
(\mu \mathrm{g} / \mathrm{ml}) \text { of petroleum ether extract }\end{array}$ & B. subtilis & P. aeruginosa & S. aureus & E. coli & C. albicans \\
\hline 5000 & + & + & + & + & + \\
\hline 2500 & + & + & + & + & + \\
\hline 1250 & + & + & + & + & + \\
\hline 625 & + & + & + & $\beta$ & + \\
\hline 312.5 & + & + & + & - & + \\
\hline 156.25 & + & + & $\beta$ & - & + \\
\hline 78.125 & B & + & - & - & + \\
\hline 39.062 & - & + & - & - & $\beta$ \\
\hline 19.331 & - & $\beta$ & - & - & - \\
\hline 9.765 & - & - & - & - & - \\
\hline 4.882 & - & - & - & - & - \\
\hline 2.441 & - & - & - & - & - \\
\hline 1.2205 & - & - & - & - & - \\
\hline 0.610 & - & - & - & - & - \\
\hline 0.305 & - & - & - & - & - \\
\hline
\end{tabular}

-Resistance (growth of bacteria/fungi or turbidity);+:Concentrations show no turbidity (inhibition of bacterial growth); $\beta$ : Least concentration showing no turbidity (MIC) 
Table 4: Minimum bacterial concentration (MBC) values for bacterial strain against petroleum ether extract of seed of Santalum album Linn

\begin{tabular}{|c|c|c|c|c|c|}
\hline Concentration of petroleum ether extract $(\mu \mathrm{g} / \mathrm{ml})$ & B. subtilis & P. aeruginosa & S. aureus & E. coli & C. albicans \\
\hline 5000 & + & + & + & + & + \\
\hline 2500 & + & + & + & + & + \\
\hline 1250 & + & + & + & + & + \\
\hline 625 & + & + & + & + & + \\
\hline 312.5 & + & + & + & $\beta$ & + \\
\hline 156.25 & + & + & $\beta$ & - & + \\
\hline 78.125 & + & + & - & - & + \\
\hline 39.062 & B & + & - & - & + \\
\hline 19.331 & - & + & - & - & + \\
\hline 9.765 & - & + & - & - & $\beta$ \\
\hline 4.882 & - & $\beta$ & - & - & - \\
\hline 2.441 & - & - & - & - & - \\
\hline 1.2205 & - & - & - & - & - \\
\hline 0.610 & - & - & - & - & - \\
\hline 0.305 & - & - & - & - & - \\
\hline
\end{tabular}

-Resistance (growth of bacteria/fungi or turbidity);+:Concentrations show no turbidity (inhibition of bacterial growth); $\beta$ : Least concentration showing no turbidity (MIC)

\section{DISCUSSION}

Santalum album Linn. (family: Santalaceae) commonly known as sandalwood and medicinally useful for the treatment of skin disorders, bronchitis, fever, heart ailments, urinary tract infection and inflammatory disorders[3]. In the present study, phytochemical screening of petroleum ether extracts shown the presence of fat, oil and traces of terpenoids with asteroid. Presence of Santalbic acid in petroleum ether extract was confirmed by supporting results of UV, IR, and NMR analysis. Petroleum ether extracts exhibited antimicrobial activity against all five microorganisms. From zone of inhibition, petroleum ether extract showed prominent antibacterial activity than ethanolic extracts. Petroleum ether extract of seed of $S$. album was more active against B.subtilis and fungus $C$. albicans. Petroleum ether extract of $S$. album seed was also active against gram-positive bacteria $S$. aureus while it is less effective against gram-negative bacteria $P$. aeruginosa and E. coli. The MIC and MBC values of petroleum ether extract for S. Album was observed similarly as $156.25 \mu \mathrm{g} / \mathrm{ml}$. It is worth mentioning that in the present study petroleum ether extract exhibited significant antimicrobial activity towards gram-positive bacterial strains studied and comparable to the standard antibiotic drug. These results may justify the use of $S$. album in traditional medicines for treating skin diseases and urinary infectious disease. Thus the present study could have clinical importance also.

Antimicrobial activity of sandalwood oil against bacterial and fungal pathogens shown with MIC values in the limit of 50>1000 ppm [21]. In addition, it is well recognized that cytoplasm membrane coagulation, electron flux and imbalance of active transport, the breakdown of protons motive force are major actions that involve in antimicrobial property of phytochemicals. Santalbic acid is a major constituent of the S. album seeds. In some standardized bioassays it was found effective against gram-positive bacteria and several pathogenic fungi whereas the unsaponified oil was observed inactive [22].

In the present study, terpenoid-rich sandalwood oil is a strong bacteriostatic agent, as recommended according to MIC values (up to $500 \mu \mathrm{g} / \mathrm{ml}$ ) based classification of plants [23].According to the previous report, ethanolic extracts of $S$. album seeds does not have antibacterial properties [24], study indicating that ethanol does not extract out such principles, whereas petroleum ether from seeds shows antimicrobial potential in the present study. Phenolics and terpenoids are major categories of a compound already reported for the antibacterial property. S. album seeds oil constituents and their synthetic analogues are reported as strong antimicrobial and antibacterial agents $[25,26]$.In the previous research work, S. album essential oil found effective significantly against E. coli and Bacillus mycoides[27].It also showed significant inhibitory effect most of the bacterial strains except Pseudomonas aeruginosa[28].

In the chromatographic study, the presence of santalbic acid as an active constituent was confirmed and may be responsible for the antimicrobial activity of sandalwood. Santalbic acid is a very nonpolar constituent present in S. Album seeds have been found effective against some pathogenic fungi and Gram-positive bacteria [22].In another statement, essential oils that consist of various ranges of terpenoid compounds are also known for their strong in vitro antifungal properties [29].

\section{CONCLUSION}

Terpenoids are also a wide group of a compound that can alter the cell morphology by manipulating the osmotic pressure of the cell, resulting in disrupting the cytoplasmic membrane and causing the release of cell constituents. Although further research work is required to identify responsible constituents in the extract, the petroleum ether extract showed the lowest MIC values, suggesting that nonpolar constituents are most active antimicrobial compounds. From above results, it was concluded that petroleum ether extract has antimicrobial activity against both gram positive, gram negative and fungal strain selected in the present study. Our findings also indicate that santalbic acid from petroleum ether extract of S. album seeds with possible high potency could serve as chemotherapeutic agents.

\section{ACKNOWLEDGEMENT}

The authors are thankful to the BSI (Botanical Survey of India), Pune, Maharashtra, India, for providing the necessary facilities to identify the plant material. Author also grateful to Department of Microbiology, R. C. Patel Art Science and Commerce College, Shirpur, Maharashtra, India, to provide microbial stains.

\section{AUTHORS CONTRIBUTION}

The experimental work was done by Vaishali Patil under the supervision of Dr. Gautam P Vadnere. Md. Rageeb Usman participated in manuscript preparation and revised in final version by Santram Lodhi.

\section{CONFLICT OF INTERESTS}

Authors do not have any conflict of interest

\section{REFERENCES}

1. Anonymous. The Ayurvedic Pharmacopoeia of India. (1 $1^{\text {sted.) }}$ III(I): Ministry of health and family welfare, the government of India, New Delhi; 2001.

2. Nadkarni K. The Indian MateriaMedica, with Ayurvedic, Unani and Home Remedies. Revised and enlarged by Nadkarni, A. Reprint, Bombay popular Prakashan PVP, Bombay; 1954.

3. Kirtikar K, Basu B.Indian Medicinal Plants.II. Internationl book of distributors, Dehradun; 2005.

4. Khare C. Indian medicinal plants. An illustrated dictionary, Springer-Verlag Berlin/Heidelberg, USA; 2007.

5. Jones C, Ghisalberti E, Plummer J,Barbour EL.Quantitative cooccurance of sesquiterpenes: a tool for elucidating their 
biosynthesis in Indian sandalwood, (Santalum album).Biochem J 2006;119:651-7.

6. Rangari V. Phrmacognosy and phytochemistry. 1st ed. Career publications, Nasik; 2005.

7. Kim TH, Ito H, Hatano T, Hasegawa T, Akiba A, Machiguchi T, et al. New antitumor sesquiterpenoid from Santalum album of Indian origin. Tetrahedron 2006;62:6981-9.

8. Kim TH, Ito H, Hatano T, Hasegawa T, Akiba A, Machiguchi T, et al. Bisabolane and santalane type sesquiterpenoids from Santalum album of East Indian origin. J Nat Prod2005;68:1805-8.

9. Demole E, Demole C, Paul E.A chemical investigation of the volatile constituents of East Indian sandalwood oil (Santalum album). Planta Med 2004;70:3-7.

10. Brunke J, Vollhardt J. Cyclosantalal and epicyclosantalal new sesquiterpene aldehydes from east Indian sandalwood oil. Flavour Fragrance J1995;10:211-9.

11. Anonymous. The wealth of India, A dictionary of India raw materials and industrial product. Istsupplement series (Raw materials), 5 (R-Z). New Delhi: National institute of science communication and information resources council of scientific and Industrial research, New Delhi; 2004.

12. Jha N.Santalum album:sandalwood.Phytopharm;2008. p. 3-12.

13. Pasha M, Ahmad F. Synthesis of the oxygenated fatty acid ester from santalbic acid ester. Am Oil ChemSoc1993;28:1027-31.

14. Anil S, Sankara R. Calcium-mediated signalling during sandalwood somatic embryogenesis. Role of exogenous calcium as a second messenger. Plant Physiol2000;123:1301-12.

15. Bisht R, Chanyal S, Agrawal PK. Antimicrobial and phytochemical analysis of leaf extract of medicinal fruit plants. Asian J Pharm Clin Res 2016;9:131-6.

16. Pandey P, Garg A, Singh V, Shukla A. Evaluation of anthelmintic and antimicrobial activity of Ursolic acid obtained from Tulsi (Ocimum sanctum). Asian J Pharm Pharmacol 2016;2:67-71.

17. Aina DA, Olawuyi OJ, Mensah-Agyei GO, Olaiya AR, AdeoyeIsijola MO. Comparative phytochemical evaluation, antimicrobial and antioxidant properties of methanolic and ethanolic extracts of-A Nigerian Mushroom. Adv Pharm J 2016;1:38-42.
18. Panda SP, Haldar PK, Das S. In vitro hypoglycemic and antimicrobial activity of Cucumiscallosus (Rottl.) Cogn Fruit. Asian J Pharm Clin Res 2016;9:77-81.

19. Soni A, Dahiya P. Screening of phytochemicals and antimicrobial potential of extracts of Vetiverzizanoides and Phragmiteskarka against clinical isolates. Int J Appl Pharm 2015;7:22-4.

20. Jie M, Pasha M, Ahmad F. Ultrasound-assisted synthesis of santalbic acid and a study of triacylglycerol species in Santalum album Linn. seed oil. Lipids 1996;31:1083-9.

21. Morris JA, Khettry A, Seitz EW. Antimicrobial activity of aroma chemicals and essential oils. J Am Oil ChemSoc1979;56:595-603.

22. Jones GP, Rao KS, Tucker DJ, Rivett DE. Antimicrobial activity of santalbic acid from the oil of Santalumacuminatum (Quandong). PharmaBiol1995;33:120-3.

23. Aligiannis N, Kalpotzakis E, Mitaku S, Chinou IB. Composition and antimicrobial activity of the essential oils of two Origanum species. J Agric Food Chem2001;40:4168-70.

24. Patil V, Vadnere GP, Patel N. Absence of antimicrobial activity in analcoholic extract of Santalum album Linn. J Pharm Negat Results 2011;2:107-9.

25. Jirovetz L, Buchbauer G, Denkova Z, Stoyanova A, Murgov I, Gearon V, et al. Comparative study on the antimicrobial activities of different sandalwood essential oils of various origin. FlavourFragr J 2006;21:465-8.

26. Misra BB, Dey S. Comparative phytochemical analysis and antibacterial efficacy of in vitro and in vivo extracts from East Indian sandalwood tree (Santalum album L.). LettAppl Microbiol 2012;55:476-86.

27. Chourasia OP. Antibacterial activity of the essential oils of Santalum album and Glossogynepinnatifida. Indian Perfume 1978;22:205-6

28. Skaltsa HD, Demetzos C, Lazari D,Sokovic M. Essential oil analysis and antimicrobial activity of eight stachys from greece. Phytochemistry2003;64:743-52.

29. Mondello F, de Bernardis F, Girolamo A, Cassone A, Salvatore G. In vivo activity of terpinen-4-ol, the main bioactive component of Melaleucaalternifolia Cheel (tea tree) oil against azolesusceptible and-resistant human pathogenic Candida species. BMC Infect Dis 2006;6:158. 